\title{
Offer Development for Clients Aged 55-70 in the Sector of Spa Enterprises
}

\author{
Urszula Bąkowska-Morawska \\ Wroclaw University of Economics, Faculty Economy, Management and Tourism, Wroclaw, Poland \\ urszula.bakowska-morawska@ue.wroc.pl
}

\begin{abstract}
In recent years, as a result of lifestyle changes, attracting more attention to health and living comfort, demographic changes and growing expenditure on preventive health care, the market offer reflecting expectations of senior citizens has been rapidly developing in Europe. The aging population, however, at the same time wealthy and aware of civilization threats, expect a different approach to meeting their needs. The comprehensive offer is supposed to include relaxation and leisure, comfort and safety of the destination, various forms of activities in free time, adequate medical care, physiotherapy, beauty treatment and a proper diet. In Germany, Austria, the Czech Republic or Poland the offer of spa enterprises, i.e. companies offering preventive health care services based on natural resources is currently subject to intensive modernization. The purpose of the study is to determine the directions of changes in the market offer ensuring meeting the needs of senior citizens in an optimal way. The research was based on interviews with chief executive officers, the observations made by the author - a manager herself and the analysis of the collected empirical material. As a result of the conducted research, new expectations of customers aged 55-70 were identified. They refer to the individualisation of health care during therapeutic stays, based on the offer developed taking into account due respect for the environment and targeted at a specific health problem. Such approach requires implementing significant changes in business models of the analysed enterprises.
\end{abstract}

KEYWORDS: offer for clients in health care, health and care management article, formatting, guidelines

\section{Introduction}

In recent years, as a result of lifestyle changes, attracting more attention to health and living comfort, demographic changes and growing expenditure on preventive health care, the market offer reflecting expectations of senior citizens has been rapidly developing in Europe. Aging of population in majority of nations along with other changes regarding mature population such as socio-demographics, health status and travel behavioral patterns is one of primary reasons for the development of appealing tourism target group that can be referred to as the senior tourists segment, which is nowadays a part of the global tourism and travel industry (Patterson 2006; Schroder \& Widmann 2007, 3-17; Nimrod \&Rotem 2010, 65-78). The aging population, however, at the same time wealthy and aware of civilization threats, expect a different approach to meeting their needs. The comprehensive offer is supposed to include relaxation and leisure, comfort and safety of the destination, various forms of activities in free time, adequate medical care, physiotherapy, beauty treatment and a proper diet.

Spa and therapeutic treatment offered in health resorts remains the essential component of health care system in Poland. It is an organized activity consisting in the provision of health care services covering spa treatment or spa rehabilitation and carried out in a health resort by the spa health care enterprises or outside a health resort in hospitals and sanatoriums located in e.g. adequately arranged underground mining tunnels, using natural conditions such as: medicinal properties of natural raw materials (e.g. therapeutic mud, thermal spring water, brine, crystalline salt), healing properties of the climate and the microclimate, supported by the appropriate physiotherapy treatment (Act of 28 July 2005).

In the course of spa treatment patients carry out comprehensive treatment programmes including primarily: balneotherapy, kinesiotherapy, physiotherapy, health education, pharmacotherapy and dietary treatment.

Poland has 45 statutory health resorts (and 1 health resort arranged in an underground mining tunnel) located throughout the country - fig. 1. 
Fig. 1 Spa health care enterprises in Polen

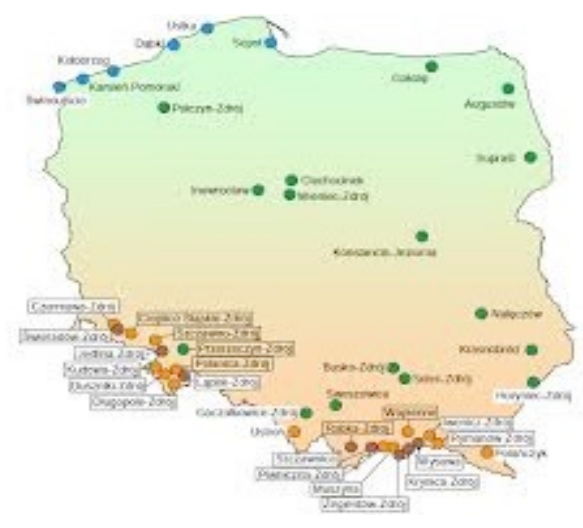

Spa health care enterprises offer approximately 44.000 beds (of which approx. 35.000 are provided in spa sanatoriums and approx. 8.000 in spa hospitals). In addition, spa municipalities (an administrative area which was granted the Health Resort statute) offer a well-developed tourist base (hotels, guest houses, $\mathrm{B} \& \mathrm{~B}$ accommodation) providing the total of approx. 80.000 beds as the potential accommodation facilities for the spa health care outpatient treatment.

Demographic analyses show a steady upward tendency in the number of dependent population. According to the demographic forecast ("The map of health needs related to hospital treatment for Poland", 2016 edition) by 2029 a significant increase in the share of people aged 65 and older will be recorded in the population structure of Poland: the number of people aged 65 and over will amount to 8.5 million and will constitute $23 \%$ of the total population against $15.3 \%$ in 2014 . In 2020 the old-age dependency ratio is expected to reach the proportion of 605 dependent individuals per every thousand working age persons, whereas in 2029 - 690 people, which indicates an increasing burden of dependent population on working age people. An increase in average life expectancy results in higher morbidity and disability and thus in the growing number of dependent people.

Spa treatment allowing the application of balneophysiotherapy in chronic diseases, preventive activities, convalescence after hospital conservative or surgical treatment as well as fast and effective rehabilitation is funded by the state National Health Fund (NFZ - government administration agenda). Funding is reduced from year to year, e.g. in 2009 it amounted to $1.39 \%$ of NFZ budget, whereas in 2017 to $0.88 \%$ of the budget. The demand for this type of services is so high that clients decide to fund their treatment stays from their own resources. The reasons for such situation are as follows:

- limited funding of the services by NFZ and a long waiting period for both sanatorium and hospital stays,

- increasing average life expectancy in Poland,

- increasing incidence of civilization diseases,

- increasing care for an individual health condition and general psychophysical fitness (dynamic lifestyle change).

Figure 2 presents the funding structure of spa treatment stays and shows that $56.4 \%$ of all therapeutic stays in spa health care enterprises are funded by the National Health Fund and 33.9\% by individual clients, referred to as commercial or full-paid clients. 
Fig. 2 Funding therapeutic stays for patients in health care enterprises

(spa hospital and sanatoriums)

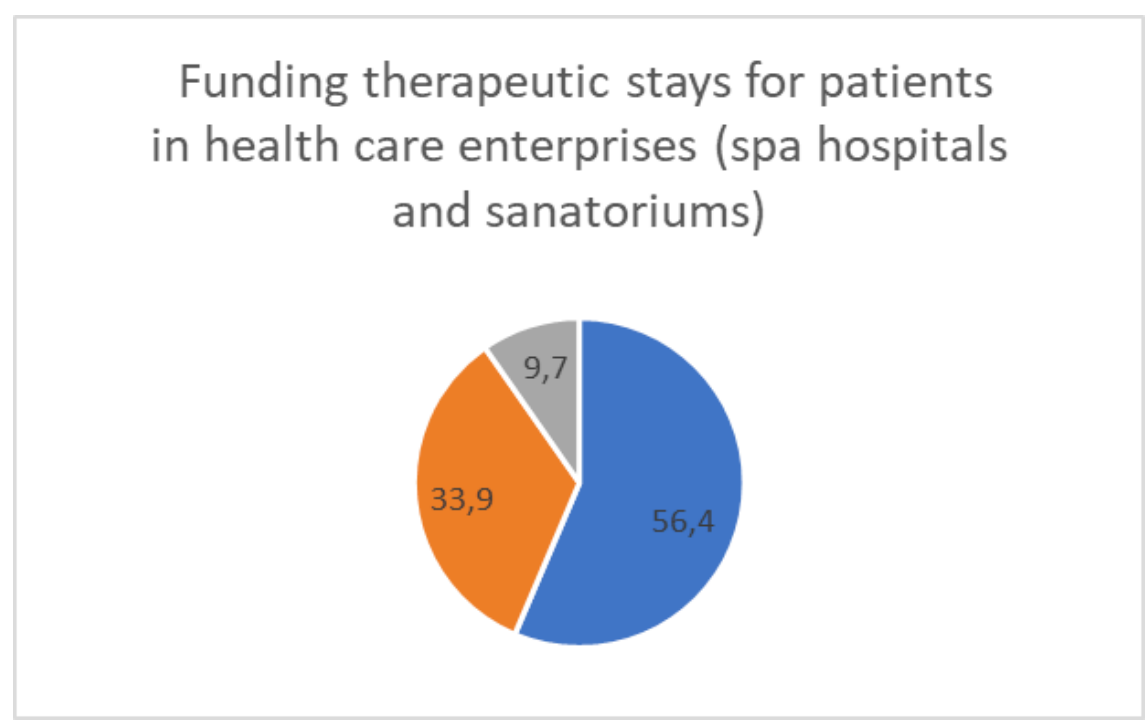

The share of full-paid clients imposes on healthcare entities taking market approach to spa treatment. As it appears from the research carried out by the author (interviews with Presidents of spa health care enterprises and the author's own managerial experience) clients/patients using therapeutic stay offers expect, from healthcare entities, such a range of services which:

- improves their well-being and reduces the burden of everyday life associated with their lost health and fitness,

- reduces morbidity and premature mortality resulting from: cardiovascular diseases, including heart attacks and strokes, malignant tumours and chronic respiratory diseases,

- reduces the consequences of injuries resulting from accidents, mainly through effective rehabilitation,

- reduces the negative effects of chronic diseases affecting the osteoarticular system,

- prevents obesity and diabetes.

\section{Case study of X spa health care enterprise}

The described spa enterprise represents a health care entity located in the area of Cieplice Health Resort (CHR), which carries out spa treatment based on natural resources, including thermal spring water.

Cieplice Health Resort, one of the oldest in Poland, was established in 1281, at the foot of the Karkonosze Mountains at an altitude of $350 \mathrm{~m}$ above sea level. For more than seven centuries, owing to its picturesque location, favourable climatic conditions and unique thermal resources of spring waters, CHR has been continuing the traditions of balneotherapy.

Throughout history the curative qualities of Cieplice spring waters have been appreciated by important and famous personalities, who took advantage of their benefits. Cieplice were visited by the recognized and holding high positions personalities, e.g. the Radziwiłł family, Primate Radziejowski, Johann W. Goethe, Prussian King Frederick William III, Hugo Kołłątaj, Izabella Czartoryska and many others, whereas the most important guest in Cieplice was, beyond any doubt, the Queen Marysieńka Sobieska accompanied by her court. Spring water deposits in Cieplice are the hottest deposits in Poland, low-mineralized, fluoride-silicon, thermal (their temperature ranges from 37 to 87 degrees Celsius). 
They are used in treating the following diseases:

- locomotor system organs (rheumatology, orthopaedics, neurology, osteoporosis),

- urinary system (urology, nephrology),

- ophthalmology.

"Cieplice Health Resort", as the only one in Poland, offers balneotherapy in the treatment of eye diseases. The basis of $X$ enterprise business activity is spa treatment offer. It means treating patients in the hospital, in the spa sanatorium and the rehabilitation centre providing over 300 rooms for the patients.

The company serves 12,000 patients annually. The spa hospital is available for patients who have recently gone through treatment in a hospital, a clinic and the patients under the care of a specialist clinic. The spa sanatorium is intended for the chronically ill visitors with less severe ailments. The treatment costs of a patient staying in a hospital or in a spa sanatorium are partly funded by the National Health Fund. The spa sanatorium is also available for patients without a referral, within the framework of a full-paid spa stay.

The share of commercial (full-paid) clients in their total number amounts to $37 \%$. Every year 12 thousand patients staying in the health resort are served by 250 people employed in the enterprise. The graph shows age median of patients staying there for therapeutic reasons.

Figure 3 Age median of patiens in X spa enterprise

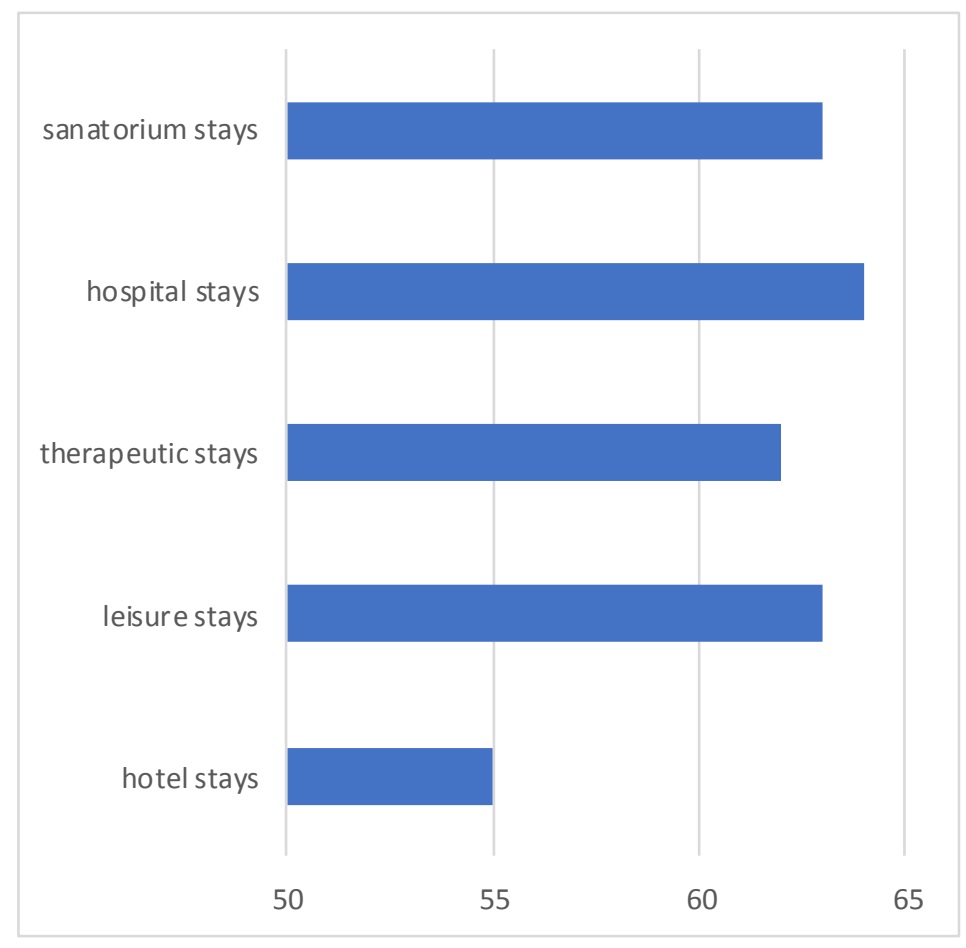

In the studied enterprise, the age median of patients (fig. 3) choosing treatment stays ranges from 62 to 64 years of age, depending on the type of selected stay. The data analysis of the studied enterprise shows a slight upward trend in the age median from year to year. The primary data indicate that the age median shows a growing tendency.

In the near future, hotels will be forced to increase the numbers of the hotel staff for the provision of elderly care, not so much at the desk, baggage delivery, and registration of transfer upon arrival and departure from the hotel, but for the provision of geriatric care, ensuring the longevity of this age group population (Nikitina, Vorontsova 2015, 846-847). Many years of experience in patient service allows a spa health care enterprise to define the framework of individual components included in the offer (Fig. 4). 
Fig. 4 The framework of individual components included in the offer

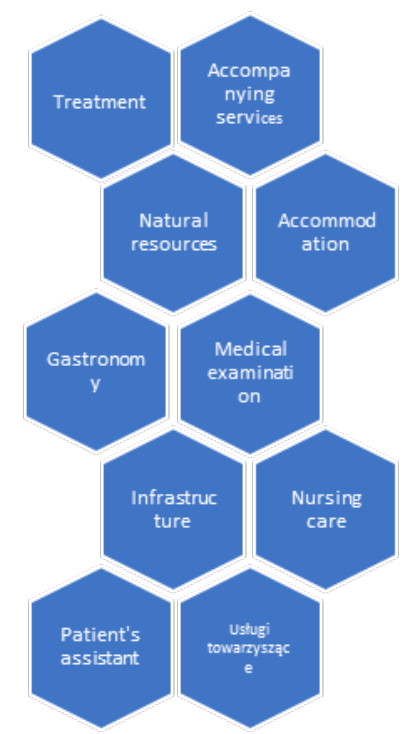

Adjusting the offer to the specificity of $55+$ clients requires introducing modifications in the selected areas. It is worth noting more frequent stays of people aged over 75 , which forces radical changes in customer service. Table 1 presents the areas of required changes, identified during interviews, along with the proposals for implementing specific solutions.

Table 1. Areas requiring changes in the offer for patients aged 55-70

\begin{tabular}{|c|c|c|}
\hline Example column 1 & Example column 2 & Example column 3 \\
\hline Employee & Infrastructure & Processes \\
\hline $\begin{array}{l}\text { New jobs: } \\
\text { Patient's assistant } \\
\text { Geriatrician } \\
\text { Balneologist } \\
\text { Paramedic capable of handling } \\
\text { seniors and helping during } \\
\text { therapeutic treatments } \\
\text { Nutritionist } \\
\text { Animators of additional activities } \\
\text { (e.g. Nordic walking) }\end{array}$ & $\begin{array}{l}\text { Rehabilitation equipment } \\
\text { meeting the requirements and } \\
\text { needs of seniors: handles in } \\
\text { bathtubs, walk-in bathtubs } \\
\text { with a side entry door, } \\
\text { exoskeletons, devices } \\
\text { working with multimedia } \\
\text { applications }\end{array}$ & $\begin{array}{l}\text { Extending the activity time } \\
\text { Individualized service with } \\
\text { continuous monitoring } \\
\text { Frequent repetition of the same } \\
\text { activities } \\
\text { Visualization of tasks and sound } \\
\text { amplification of the instructions } \\
\text { during treatment }\end{array}$ \\
\hline Requirements for employees & $\begin{array}{l}\text { Requirements for } \\
\text { infrastructure }\end{array}$ & Requirements for processes \\
\hline $\begin{array}{l}\text { Additional skills including: } \\
\text { ability to listen, patience, } \\
\text { empathy }\end{array}$ & $\begin{array}{l}\text { Easy to use, intuitive control } \\
\text { panel }\end{array}$ & $\begin{array}{l}\text { Permanent contact with the front } \\
\text { office staff, paramedics and } \\
\text { nurses through paging systems }\end{array}$ \\
\hline $\begin{array}{l}\text { Trainings in the approach to } \\
\text { seniors, including how to } \\
\text { communicate, understand } \\
\text { individual needs and gain trust }\end{array}$ & $\begin{array}{l}\text { Easy access to treatment } \\
\text { facilities: stairs, platforms, } \\
\text { handrails. Supporting the } \\
\text { treatment using natural } \\
\text { resources and technical } \\
\text { infrastructure, advanced } \\
\text { medical equipment }\end{array}$ & $\begin{array}{l}\text { Mobile applications facilitating } \\
\text { communication with employees } \\
\text { through personal smartphones }\end{array}$ \\
\hline
\end{tabular}




\begin{tabular}{|c|c|c|}
\hline \multicolumn{3}{|c|}{ Areas requiring changes in the offer for patients aged $55-70$} \\
\hline Employee & Infrastructure & Processes \\
\hline $\begin{array}{l}\text { New jobs: } \\
\text { Patient's assistant } \\
\text { Geriatrician } \\
\text { Balneologist } \\
\text { Paramedic capable of } \\
\text { handling seniors and helping } \\
\text { during therapeutic treatments } \\
\text { Nutritionist } \\
\text { Animators of additional } \\
\text { activities (e.g. Nordic } \\
\text { walking) }\end{array}$ & $\begin{array}{l}\text { Rehabilitation equipment meeting } \\
\text { the requirements and needs of } \\
\text { seniors: handles in bathtubs, } \\
\text { walk-in bathtubs with a side entry } \\
\text { door, exoskeletons, devices } \\
\text { working with multimedia } \\
\text { applications }\end{array}$ & $\begin{array}{l}\text { Extending the activity time } \\
\text { Individualized service with } \\
\text { continuous monitoring } \\
\text { Frequent repetition of the same } \\
\text { activities } \\
\text { Visualization of tasks and } \\
\text { sound amplification of the } \\
\text { instructions during treatment }\end{array}$ \\
\hline $\begin{array}{l}\text { Requirements for } \\
\text { employees }\end{array}$ & $\begin{array}{l}\text { Requirements for } \\
\text { infrastructure }\end{array}$ & Requirements for processes \\
\hline $\begin{array}{l}\text { Additional skills including: } \\
\text { ability to listen, patience, } \\
\text { empathy }\end{array}$ & $\begin{array}{l}\text { Easy to use, intuitive control } \\
\text { panel }\end{array}$ & $\begin{array}{l}\text { Permanent contact with the } \\
\text { front office staff, paramedics } \\
\text { and nurses through paging } \\
\text { systems }\end{array}$ \\
\hline $\begin{array}{l}\text { Trainings in the approach to } \\
\text { seniors, including how to } \\
\text { communicate, understand } \\
\text { individual needs and gain } \\
\text { trust }\end{array}$ & $\begin{array}{l}\text { Easy access to treatment } \\
\text { facilities: stairs, platforms, } \\
\text { handrails. Supporting the } \\
\text { treatment using natural resources } \\
\text { and technical infrastructure, } \\
\text { advanced medical equipment }\end{array}$ & $\begin{array}{l}\text { Mobile applications facilitating } \\
\text { communication with employees } \\
\text { through personal smartphones }\end{array}$ \\
\hline
\end{tabular}

Table 2. shows a model presentation of the customer service process as the subject of the offer dedicated to patients aged 55-70. The table highlights the identified areas of necessary changes.

Table 2. Patient care process

\begin{tabular}{|c|c|c|}
\hline Who/department & \begin{tabular}{l|l|} 
& Activities \\
\end{tabular} & Comments \\
\hline Front office & $\begin{array}{l}\text { A visit in the front office, a } \\
\text { preliminary interview about favourite } \\
\text { TV shows, the way of spending free } \\
\text { time in order to enter these } \\
\text { expectations in the smartphone. }\end{array}$ & $\begin{array}{l}\text { The patient receives a smartphone } \\
\text { with an application reminding } \\
\text { him/her about the treatment } \\
\text { sessions and suggested leisure time } \\
\text { activities using voice and image. } \\
\text { The application will help to move } \\
\text { around on the site. The alternative } \\
\text { is to provide a paper version of the } \\
\text { building plan to be used until } \\
\text { smartphone applications are ready. }\end{array}$ \\
\hline Patient's assistant & $\begin{array}{l}\text { Assistance to the room using a } \\
\text { smartphone or a map. }\end{array}$ & \\
\hline Nutritionist & $\begin{array}{l}\text { Specifying the proper diet and the } \\
\text { place of having meals (table } \\
\text { number). }\end{array}$ & \\
\hline Nurse & $\begin{array}{l}\text { Interview and setting the time of } \\
\text { medical appointment. }\end{array}$ & \\
\hline Physician & $\begin{array}{l}\text { Medical consultation and treatment } \\
\text { ordination. }\end{array}$ & \\
\hline Treatment planner & Treatment planning. & \\
\hline
\end{tabular}




\begin{tabular}{|l|l|l|}
\hline Patient's assistant & $\begin{array}{l}\text { The assistant informs about the } \\
\text { treatment plan for the entire stay and } \\
\text { assists the patient to the first meal. }\end{array}$ & \\
\hline & $\begin{array}{l}\text { First meeting with the patients after } \\
\text { the first meal regarding the } \\
\text { organization of their stay. The } \\
\text { second meeting on the next day } \\
\text { about extra activities: culture, sport, } \\
\text { trips. }\end{array}$ & \\
\hline
\end{tabular}

\section{Conclusion}

In the author's opinion, the proposed directions of changes in the offer addressed to senior citizens require a new model to be developed for running the discussed business. A new one, because the guidelines for its development and functioning question the traditional methods for achieving business efficiency. In the new business model, social objectives are combined with economic goals, often forcing the management to change the priorities of operation. The service offered to seniors cannot be based on economic criteria only because it requires, among others:

- more time devoted to performing planned activities,

- repeating them,

- additional rehabilitation facilities or their modification,

- more employees assigned to assist patients,

- as well as completely new jobs and the corresponding competencies.

Future research should focus on the identification of assessment criteria for the efficiency of new business models dedicated to 55+ clients. In addition to economic assessment criteria, such as EBiT, RevPar, ADR, non-financial factors should also be examined, e.g. related to improving patients' well-being.

\section{References}

Act of 28 July 2005 on spa treatment, health resorts and protection zones of health resorts and health resort municipalities (i.e. Journal of Laws 2017, item 1056)

Bąkowska-Morawska U. 2014. "Barriers in Knowledge Sharing vs the Ability to Create Tourism Supply Chains." In Proceedings of the 15th European conference on Knowledge Management edited by C. Vivas, P. Sequiera, Santarem: ACPI Pub. 72-79.

Nikitina O., Vorontsova. G. 2015. “Aging Population and Tourism: Socially Determined Model ofConsumer Behavior in the "Senior Tourism." In Procedia - Social and Behavioral Sciences 214 ( 2015 ): 845 - 851.

Nimrod G., Rotem, A. 2010. "Between relaxation and excitement: activities and benefits gained in retirees' tourism." Journal of tourism 12 (1): 65-78.

Patterson I. 2006., Growing older: tourism and leisure behavior of older adults". Cambridge CaBI Pub.

Schroder A, Widmann, T. 2007. "Demographic change and its impact on the travel industry: oldies - nothing but goldies?" In Trends and Issues in global tourism, edited by R. Conrady, M. Buck, 3-17. Berlin and Heidelberg: Springer. 